\title{
THE MEDIA OF BUGIS LITERACY: A CODA TO PELRAS
}

\author{
Campbell Macknight ${ }^{*}$ \\ Australian National University, Australia \\ email: macknight@ozemail.com.au
}

Published online: 15 September 2016

To cite this article: Macknight, C. C. 2016. The media of Bugis literacy: A coda to Pelras. In Orality, writing and history: The literature of the Bugis and Makasar of South Sulawesi, ed. Druce, S. C. International Journal of Asia Pacific Studies 12 (Supp. 1): 53-72, http://dx.doi.org/10.21315/ijaps2016.12.s1.4

To link to this article: http://dx.doi.org/10.21315/ijaps2016.12.s1.4

\begin{abstract}
The existence of literacy implies a range of practical questions about writing. While attention has been given to the form of Bugis writing, there are also issues around the mechanics of writing, that is, the ways in which marks have been made on various surfaces. Bugis literacy, which began with palm leaf manuscripts, has been overwhelmingly in the form of paper manuscripts, though examples of printing, inscriptions on silver and on earthenware are also discussed and illustrated. The relationship between medium and the function of writing is explored in particular cases.
\end{abstract}

Keywords: Bugis writing, lontara', South Sulawesi manuscripts, South Sulawesi silver, South Sulawesi earthenware

Christian Pelras' magisterial survey of orality and writing in Bugis culture is rightly famous among specialists (Pelras 1979; 2010; 2016). This paper, which assumes a prior reading of Pelras, should be seen as a more detailed investigation of one aspect of Bugis literacy, though perhaps with some wider implications too. It looks at the practicalities of writing - surface and tools - to ask how this affects our understanding of written texts. 
I sit silently at a desk overwhelmed by evidence of literacy: books, journals, newspaper clippings, bills, newsletters and printed papers of various kinds, as well as notes and lists, many scribbled on the back of scrap paper. In the middle of the desk the computer screen takes pride of place and I type in text as emails or drafts such as this. Increasingly, I read directly from the screen. The media of literacy are many, though the dominant form of my literacy - the Latin alphabet adapted to English useis singular. At least within my own society, I am somewhat unusual, though by no means alone, in having some ability to read languages other than English and, in particular, to deal with some non-Latin scripts. Literacy in any form or to any degree is such an intellectual achievement that it is easy to take for granted its practicalities. Writing, understood as the transmission of language through material means, almost always intended to be apprehended visually, requires a surface and a tool with which to mark that surface.

Technology serves to define several broad classes or registers of material for literacy. Printing, that is the transfer of ink to paper, traditionally from a raised surface (letterpress), but now more usually by means of other techniques such as engraving, lithography, stencilling and yet more elaborate methods as technology advances, allows the production of multiple identical versions of text and image. The use of the manuscript register, by contrast, since it requires the direct action of a human hand to produce the signs of the text or image, whatever the medium on which the signs are produced, precludes identical versions, though the nature and extent of variation can vary across a wide range. ${ }^{1}$ A third register, even if it is not of much relevance in the case of Bugis literacy, is the digital file which allows signs to appear on a computer monitor or on paper through a "printer"-perhaps more accurately described as a writing machine. A digital file can easily be both reproduced without change, and also altered in various ways, by means of a control device - but the technology of the device is essential.

The first feature to note in Bugis literacy is the relatively small quantity of printed material. Pelras provides a general description of this and a fuller account may be found in Noorduyn's survey of Sulawesi languages (1991: 168-98). ${ }^{2}$ Until the early 20th century, most of the printing was in the lontara' script, but more recently, printed texts have usually been in one of the various Latin orthographies which have been developed to represent the language. ${ }^{3}$ Three exceptions to this are, firstly, school books designed to teach lontara' literacy, some of which have used letterpress fonts available in Makassar. Secondly, the range of translations from the Chineseadmittedly mostly into Makasar — which were published in Makassar before 
1942. These texts, which also contain many Chinese characters, seem to have been written with a brush and, from one specimen at least, the lontara' script is very poorly formed (Hamonic and Salmon 1983: 151). Thirdly, and much more significantly, from about the middle of the 20th century Pesantren As'adiyah in Sengkang has produced a wide range of religious publications in Bugis to support its work. The As'adiyah materials are either stencilled or, more usually now, produced by lithography and include other content in Arabic language and script. There is also some use of Indonesian in Latin script, particularly for matters relating to the context within which the books are produced. The high quality of the lontara' script can often make it hard to distinguish from letterpress. Figure 1 is a good example of the mixture of scripts on a single page. A notable point here is the way in which the general use of spoken Bugis and of Bugis written in lontara' script for Muslim studies constitutes part of the distinctive nature of Pesantren As'adiyah. This is an educational and religious institution with a self-consciously Bugis identity. ${ }^{4}$

As Pelras explains, however, "for the Bugis, 'writing' retains the sense of 'manuscript."' The origins of Bugis writing were undoubtedly and unsurprisingly in the form of manuscripts. In recent times, Ian Caldwell has made sustained study of early genealogical texts and suggests that the advantage of having a written record of descent provided the motive for the first Bugis writing (Caldwell 1988: 174; 1998). The astounding proliferation of genealogical information which starts in the 14th century can only be explained by the presence of a written record and it seems reasonable to date the invention of Bugis writing to that period. Given what we know about the social structure of Austronesian-speaking societies generally, this function for writing makes its adoption very believable (Macknight 1993a: 7). Moreover, much more is now known about this early period of South Sulawesi's history than when Pelras was writing and it is clear that the introduction of writing should not be seen as particularly surprising. While some degree of contact between islands in the Indonesian archipelago goes back to the arrival of Austronesian speakers, by the 14th century it can be shown that Bugis lands, both in the Cenrana valley and at the head of the Gulf of Bone, were in active trading relations with the western parts of the archipelago. There was also traffic between South Sulawesi and the southern Philippines. The fact that the script is based on the Indic system, and not the Arabic script, argues strongly for its origin before significant Muslim influence in South Sulawesi, that is before the 16th century. 


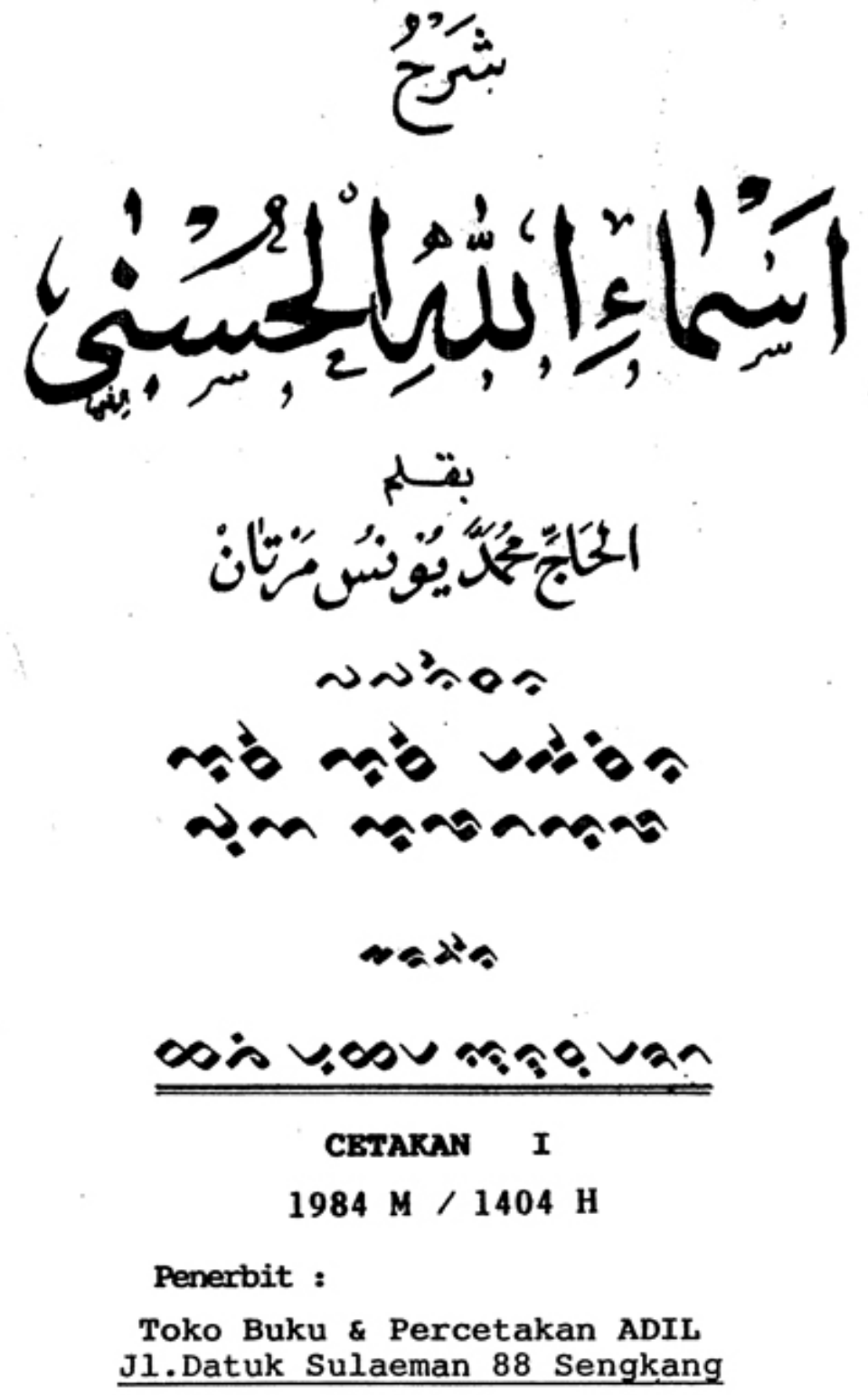

Figure 1: Title page of a book, dealing with the names of God, published for Pesantren As'adiyah in Singkang, using lithography. The Arabic and Bugis, in lontara', give information about the title and author and are handwritten, though very skilfully. The material in Latin script below gives information relevant to the context of publication and has been produced using a typewriter. The main text of the book is Bugis, handwritten in lontara', with much use of Arabic where appropriate.

As Pelras says, the Bugis word for writing, maruki', and the original meaning of the word lontara', which is now associated with both manuscripts and the writing system itself, suggest that the first Bugis writing was scratched on to a palm leaf surface. ${ }^{5}$ It is generally agreed that the form of palm leaf surface was a series of strips sewn end to end and allowing a single line of characters on one side only. This very long ribbon 
was then rolled up and mounted on a frame, allowing the text to be read in the same way as a tape cassette. What is striking about this format is its originality. The closest parallel is a letter from Brunei to the Chinese court which a 13th-century source says was brought at the end of the first millennium: "the paper was like tree-bark, but thin, smooth and glossy, and of a greenish tint, several feet long and over an inch in thickness [?width]; when rolled up, it was just as much as one could hold in the hand. The characters written upon it were fine and small" (Hirth and Rockhill 1911: 157; see Macknight 1986: 222). Even if one can perceive some link across the centuries and distance between this Brunei writing and the earliest Bugis writing, the Bugis system still shows itself as distinctive.

Even more remarkable is the script itself. It has generally been assumed, as Pelras does, that this was ultimately derived from south Indian scripts, probably by way of Java, though no one has been able to demonstrate a consistent pattern of evolution for all the aksara ${ }^{6}$ Christopher Miller (2013; in press) has recently proposed a derivation from north Indian Gujarati scripts and strong linkages with Sumatran scripts. From South Sulawesi, the concept of the scripts was taken to the southern Philippines, certainly before the Spanish arrived in the mid-16th century. There were also some more direct imitations of South Sulawesi scripts in Bima and Flores, probably from the 17 th century onwards. I accept this general outline which has only recently become clear, largely through the brilliant work of Miller.

The detailed evolution of the South Sulawesi scripts, however, still remains to be clarified. For example, it seems helpful to separate the origin of the so-called Old Makasar script (or jangang-jangang script) from the more common lontara' script used for Bugis and, most commonly in recent times, for Makasar as well, though they share features which suggest some degree of interaction. However that may be, we are here concerned only with the lontara' script, and the development of that script is a remarkable achievement.

While acknowledging the undoubted external influence, whether from Sumatra or even more directly from Gujarat, it is not too strong to speak of the "invention" of Bugis writing using the lontara' script. ${ }^{7}$ The following points indicate the extent of innovation:

- the absence of the virama, that is the means of writing a consonant without an attached vowel, reflects the unusual and very specific nature of Bugis (and Makasar) 
- the re-ordering of the characters, which is important in learning any writing system, matches the frequency of use in Bugis and Makasar - the actual form of the characters, after radical simplification, is such that the most basic shapes are also the most common characters

The radical simplification of the form of characters means that all characters are derived from a diagonal line and a dot. That implies what might be described as an angular script with approximately square angles between diagonal lines. I believe that this radical simplification is associated with inscribing the characters on to palm leaves as found in the long ribbons described above. ${ }^{8}$

No palm leaf strip manuscripts survive from anything like the period when the Bugis started to write. Tol (2009: 200-201) dates the famous example in the National Library of Indonesia (PNRI Peti 40/780) to between 1620 and 1898 and suggests that it might have been a specially commissioned antique form. Similarly, the example of palm leaf strips presented by Matthes to the Museum voor Volkenkunde in Leiden in $1871^{9}$ seems to be intended as a demonstration model. In the Tropenmuseum in Amsterdam and dated before 1887, a specially set up arrangement shows how a board underneath the palm leaf script allowed pressure to be applied as the characters were inscribed. As Figure 2 shows, the characters have not yet been made easier to read by the application of blacking. The final effect is clearly visible in Figure 3, a full roll manuscript acquired from Bua in the headwaters of the Pangkajene river in 1906 or 1907 and containing a short version of a well-known La Galigo episode. A handful of other examples are known, but none seem to be earlier than the 19th century. ${ }^{10}$

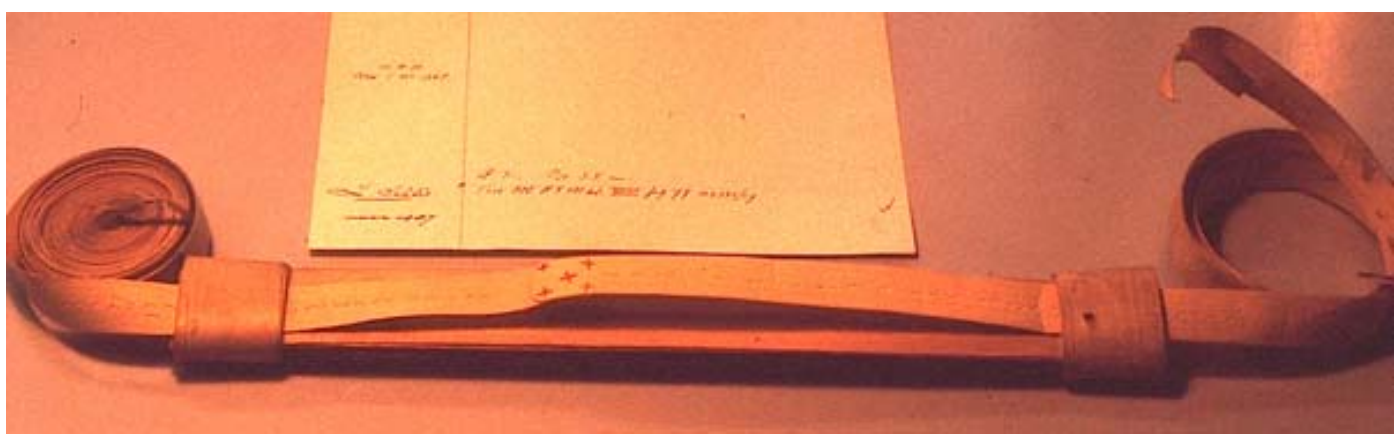

Figure 2: A long strip made up of sections of palm leaf stitched together and tied over a wooden board to enable characters to be incised. These characters have not yet been made more legible by a wiping a blacking agent across the surface. Tropenmuseum, Amsterdam, A4517, said to date from before 1887. 


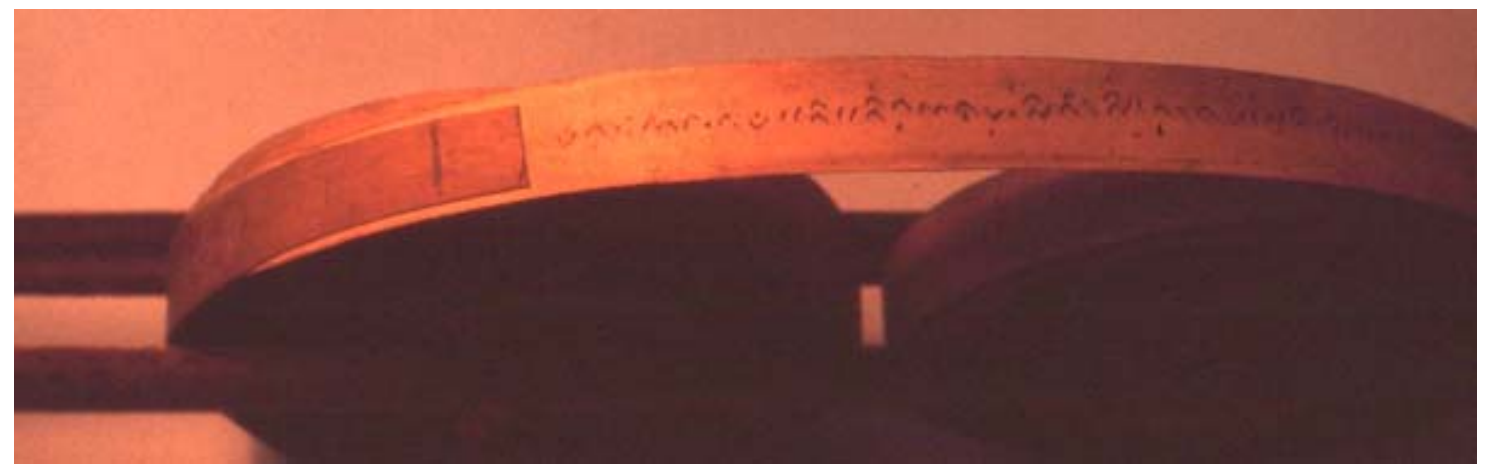

Figure 3: A palm leaf manuscript containing an episode of the La Galigo cycle, obtained in Bua, South Sulawesi, in 1906 or 1907 . The strip is $22 \mathrm{~m}$ in length. The item has been catalogued by Kern 139: 879. Tropenmuseum, Amsterdam, 673/4.

The lack of early examples of Bugis writing makes it difficult to be sure that its original form was angular, and it has to be admitted that there is no great difficulty in inscribing a curved line on a palm leaf surface, as clearly seen in manuscripts from many other traditions. Kern suggested that his "palmleaf style," of which he has a few examples on paper (Kern 1939: 390, 402, 1075-1076), derived from what has come to be seen as the standard script on paper, but I agree with Noorduyn who sees the transition going the other way (Noorduyn 1993a: 561-564). Certainly the script used on the palm leaf strips themselves is reasonably angular, though some tendency to round the angles is observable and both Kern and Noorduyn draw attention to a "vertical shift" and some distinctive usages.

If we accept that the earliest Bugis writing was on palm leaf stripsand the surviving examples show that this could include a variety of genres - the full development of Bugis written literature, especially the quantity of surviving material, must be associated with the availability of paper. Paper, and the much simpler means of making a mark on it with pen and ink, made literacy very much easier. Notice too the shift from a single line of text to a page with successive lines of text across it and the variation in the width of the stroke associated with the use of a pen. Though we cannot be sure of the detail, this new ease of literacy probably prompted or encouraged new genres of writing. ${ }^{11}$ Of course, as Pelras has shown so well, we must be careful not to assume that writing served the same purposes as it does for us and Bugis works in the manuscript register must be assessed in that context, not as printed texts.

European paper was certainly available in Makassar from the early 17th century when the first European traders arrived and there is no reason to doubt that this was also available in Bugis lands. The overwhelming majority of surviving Bugis manuscripts are written on European paper of various kinds, though these manuscripts are later than the 17th century. The 
earliest example of so-called Old Makasar or jangan-jangan script on paper appears to be the signatures to the Treaty of Bungaya in $1667^{12}$ (Tol 1996: 214, 216), but I know of no example of Bugis writing on paper before 1700. It would be interesting to discover the earliest specimen.

As Jones (1993) shows so comprehensively, the date at which paper, from whatever source, was first available anywhere in the archipelago is very difficult to determine. The earliest Malay manuscripts on European paper date from the 1520 s and Pires tells us that paper, probably from China, was brought to Melaka a decade or so before that (Jones 1993: 477, 484). Paper, pen and ink were acceptable gifts to the ruler of Brunei in 1521 (Jones 1993: 479), while in Maluku in the 1540s, "they write upon [...] palm leaves, and on paper which is imported from India; and the pens are made of ferns, for those of ducks are not known there," and in the context this is clearly Arabic script (Jacobs 1971: 123). The regular Malay word for paper, kertas, betrays its western origin, perhaps immediately from the Arabic, and its Bugis cognate is karettasa ${ }^{\prime 13}$ Given the capacity of sailors from South Sulawesi to bring home vast quantities of ceramics from western Indonesia long before writing was known, it is not difficult to account for the presence of paper in South Sulawesi by 1500, at the latest, and probably even earlier. There is also the possibility of writing on beaten bark cloth, as is the case in Sumatra, but I do not know of any significant examples in Sulawesi. Another and perhaps an even more pertinent element in the overall context is the Javanese production of beaten bark paper or dluwang which, although closely associated with Islam today, has a more complex past (Guillot 1983).

Despite the excellent introduction by Noorduyn (1993a), there is more work to be done on the understanding the varieties of Bugis handwriting. Figure 4, however, provides a good example of the standard lontara' script. This manuscript certainly dates from before 1845 . It is on very common Pro Patria European paper and this particular section is a list of the rulers of Bone in the early 18th century. The last line refers to the removal in 1715 of the ruling queen by her brother after a reign of only one year: she came back for two further periods as ruler! Since it gives her necronym, however, the text must date from after her death in 1749. The stability of the script can be seen in the regularity of the first five aksara of each line which represent the words Matinroé ri, that is regular beginning of the necronym by which rulers are conventionally known. 


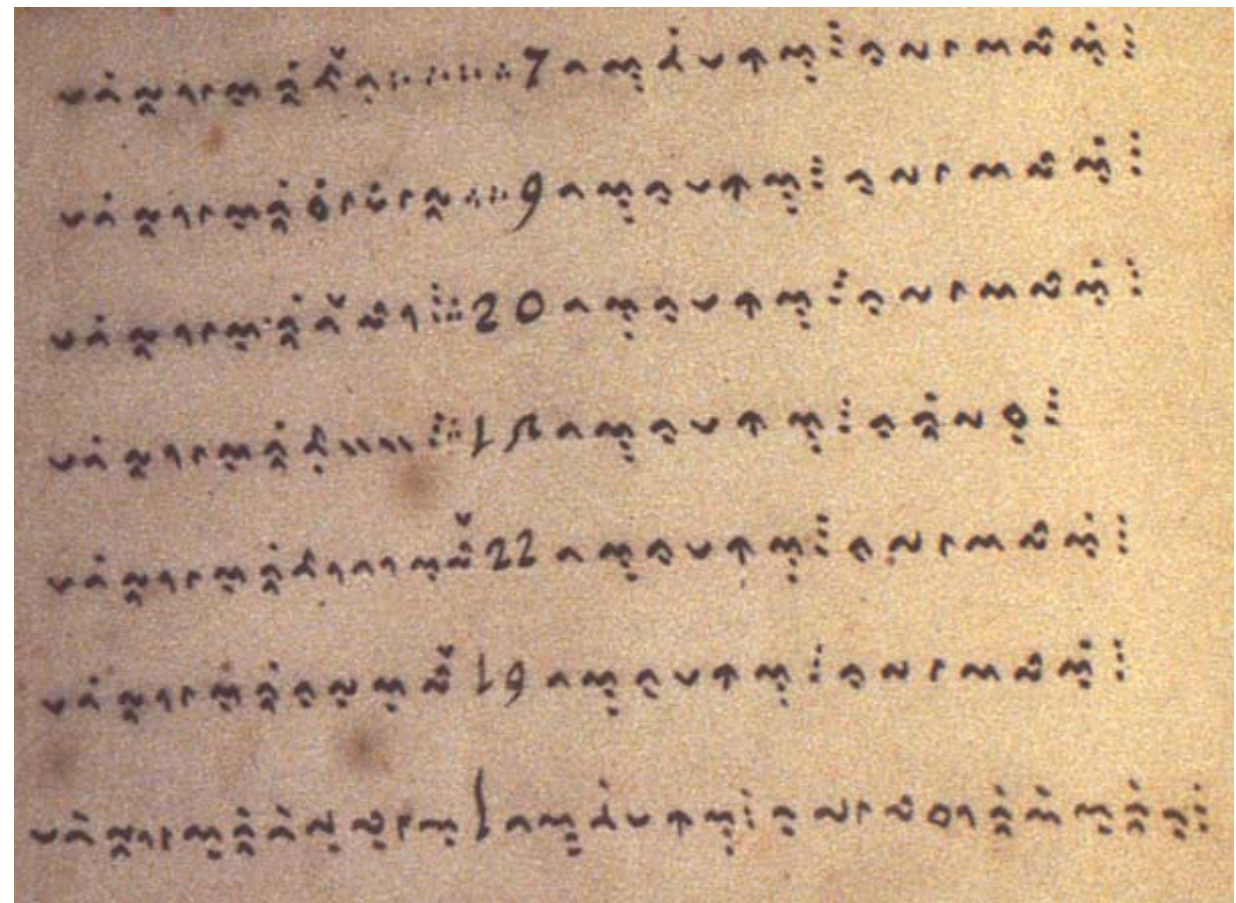

Figure 4: A specimen of typical Bugis in lontara' script. It lists 17th and 18th century rulers of Bone, giving their necronym, the length of their reign in years and how their reign ended. The regularity of the script can be observed by noting that several words are repeated on successive lines. The manuscript dates from before 1845. Berlin Ms. orient. fol. 386. It appears to have been written using a kallang, or sharpened palm leaf rib, rather than a quill or pen with a steel nib.

Figure 5 shows similar material as printed by Matthes in the first volume of his Boegineesche Chrestomathie in 1864. The evolution of this clear and elegant type face is discussed by Noorduyn (1993a: 543-544). It has served as the model for most later printing. The same sequence of aksara for Matinroé ri can be seen in the lines numbered 18 and 19. If Matthes intended his printed chrestomathies, both Bugis and Makasar, to promote the study of the languages and their literature in the first place to colonial administrators, and then to scholars generally, he succeeded in generous measure. He laid the foundations for all later study.

Several digital versions of the script are available. The XenoType version is very close to Matthes, as seen in the upper line of Figure 6. I have some personal preference for the rather softer version in the lower line. 


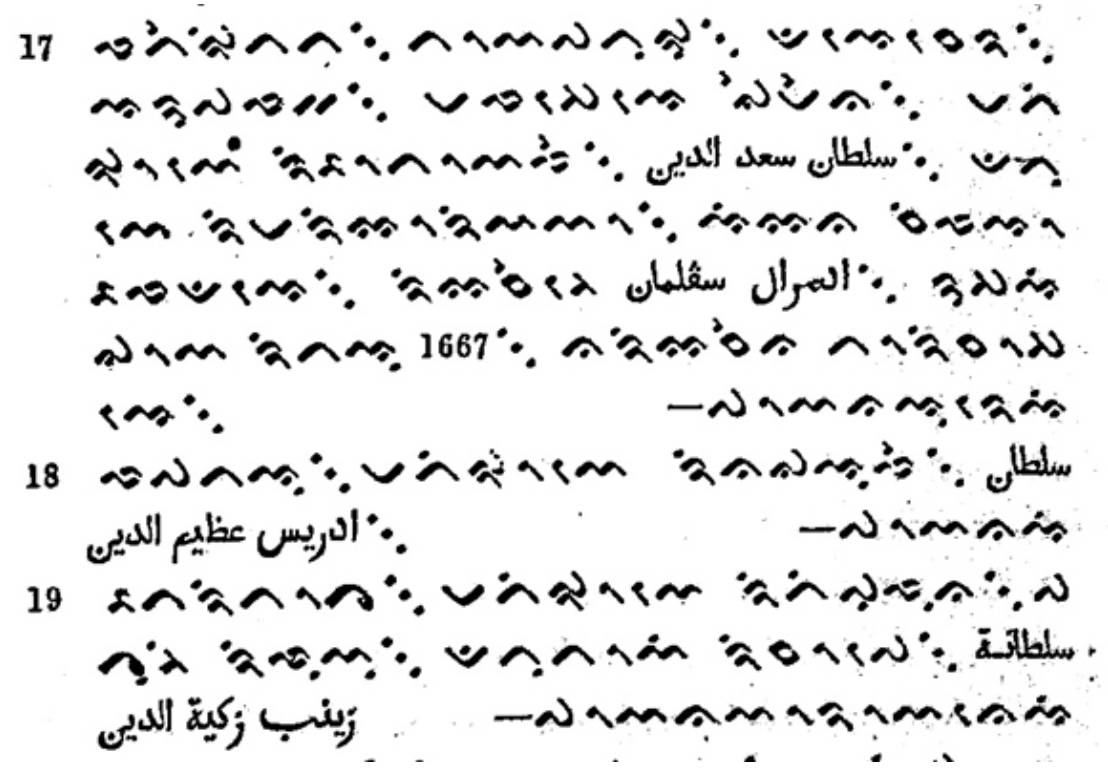

Figure 5: A specimen of letterpress lontara' script as developed for B. F. Matthes, Boegineeesche Chrestomathie in 1864. This is from volume 1, page 500 and lists rulers of Bone. These three rulers are those in the three bottom lines of Figure 4. The same necronyms for the last two can be seen in the middle of the lines numbered 18 and 19. Note the use of Arabic letterpress for their Muslim names.

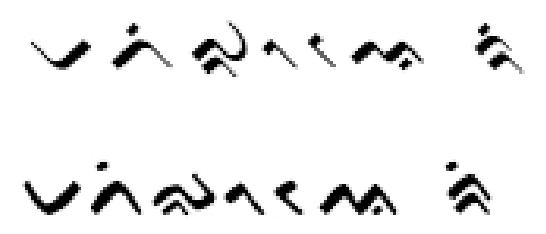

Figure 6: Digital fonts available for writing lontara'. Both spell the first element of a necronym, Matinroé ri- (he who sleeps in-). The upper line is in the XenoType Technologies Lontara font. It is based on the font developed for B. F. Matthes and shows marked difference between wide up-stroke diagonals and narrow down-stroke diagonals. The extent of this difference, which is also found in many recently copied manuscripts, may be associated with the use of a pen with a steel nib or, earlier, a quill. The lower line has been produced using the Macromedia Fontographer font creation software and is closer to manuscripts produced with a kallang, or sharpened palm leaf rib. Compare the strokes in both fonts with those in the script shown in Figure 4.

The forms of the script are, in fact, very adaptable to various media, but it is worth noting that it is not used in some contexts where it might be expected. Inscriptions on stone, for example, are not found, to my knowledge, in Sulawesi, though Noorduyn (1993b) reports a Bugis inscription, using a rounded version of the lontara' script, on a 19th-century gravestone in Brunei. Gravestones in Sulawesi often have inscriptions in Arabic script and raised calligraphic devices of great intricacy, so there is no functional reason for not using the lontara' script. 
An instructive, but little noticed, group of texts are found on silver objects, almost certainly made in South Sulawesi in the 19th and 20th centuries. The characters are formed by impressions in the silver from a series of punches. Often more than one punch is needed to create a complete character - to add a dot for example - and the same punch can be used for elements of various characters. This reminds us of the way in which the script is built up from a limited range of elements.

A good example is seen in Figure 7 where the short text merely asserts ownership of the plate. More information is provided for the bowl shown in Figure 8 where both ownership and value are given. An example which took some time to decipher is shown in Figure 9. While the force of the punch usually creates a low rise on the reverse side of the silver surface, as is clear in the previous two examples, with the bowl shown in Figure 9 the text is designed to be read on the interior base of the bowl from the ridges formed by punching a mirror image of the text from within the footring underneath the bowl. At the same time, the elaborate repoussé decoration on the exterior of the bowl is formed by pressure from the interior. A slightly more expansive inscription is seen in Figure 10. This is the bottom of a small sirih box. It makes reference to personal relations, beyond mere ownership of the box itself. ${ }^{14}$

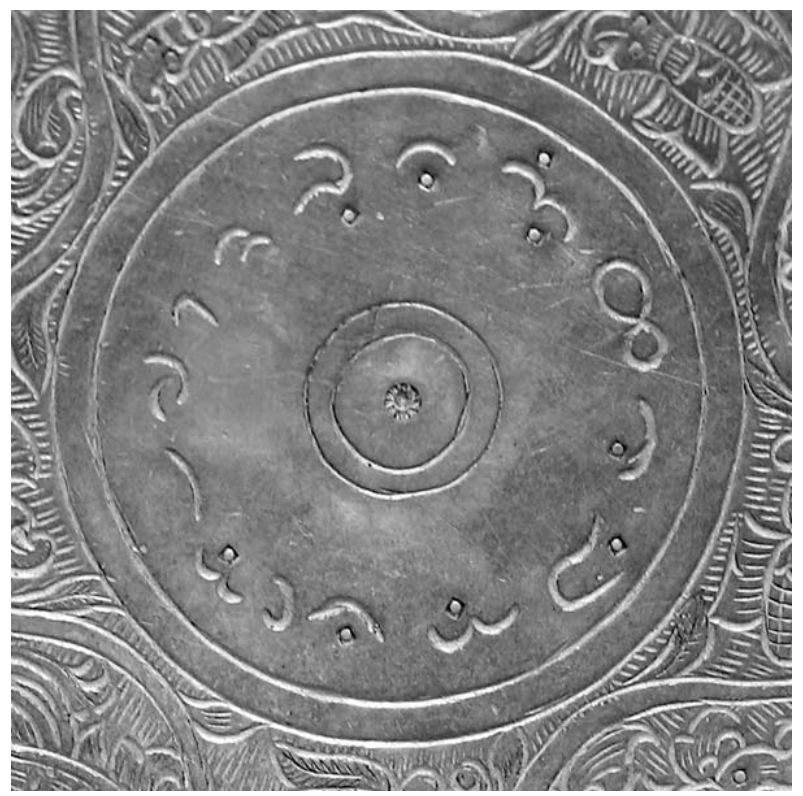

Figure 7: Impressed inscription in the centre of a small silver plate. Diameter of plate is $15 \mathrm{~cm}$. Diameter of first circle outside text is $3.2 \mathrm{~cm}$. The text reads:

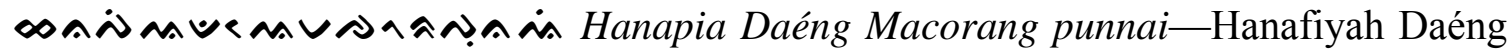
Macorang owns [this]. Notice the use of two punches to form the inverted W form for "a" and the multiple punches required for "h." The elaborate impressed decoration around the central roundell is also formed with a variety of punches. 


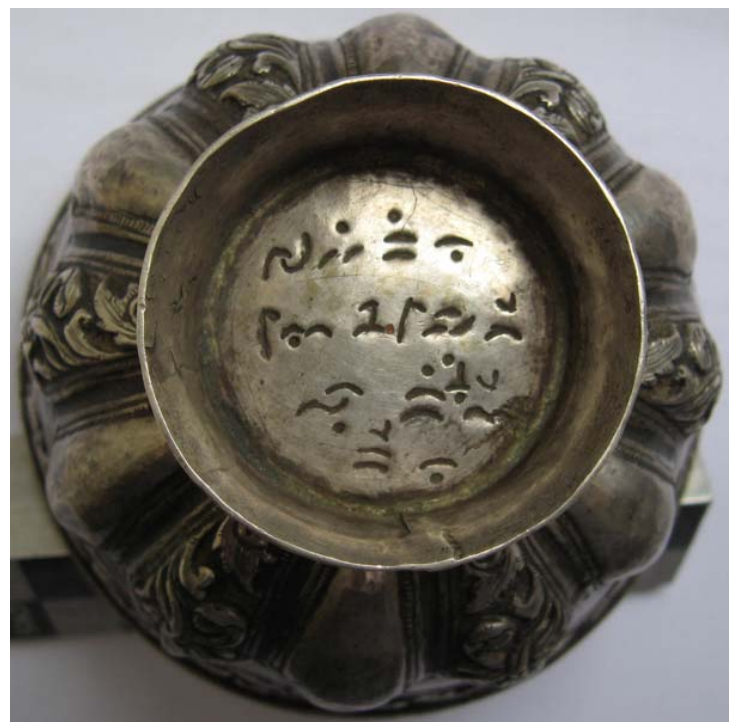

Figure 8: Impressed inscription inside the footring of a small silver bowl. Diameter of the

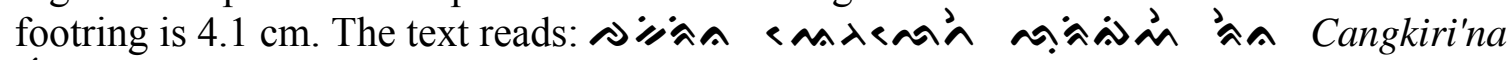
É Ngalé tellu ringgi' werre'na-Bowl of I Ngalé three ringgits its weight. [The transcription of the personal name is rather uncertain.] Notice the many instances of the use of several punches needed to form a single character and the insertion of $\dot{\boldsymbol{\alpha}}$ above the third line. The content of the text is very standard and refers to ownership and value.

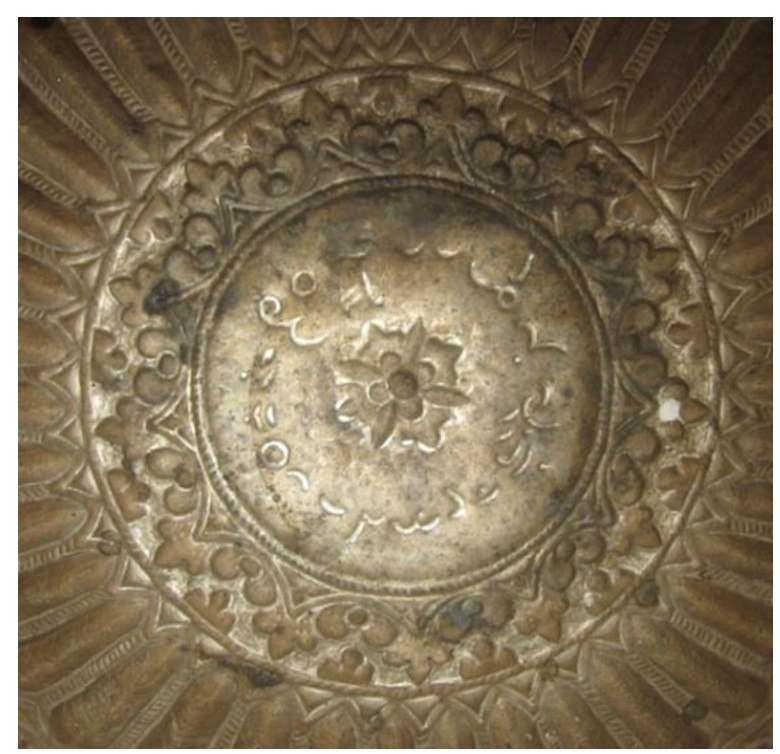

Figure 9: Raised inscription on the interior base of a silver bowl formed by punching reverse images of the characters from below. Diameter of first ring outside text is $4.2 \mathrm{~cm}$. Diameter of lip of bowl is $9.7 \mathrm{~cm}$, and height of bowl $6.3 \mathrm{~cm}$. The text, starting at the

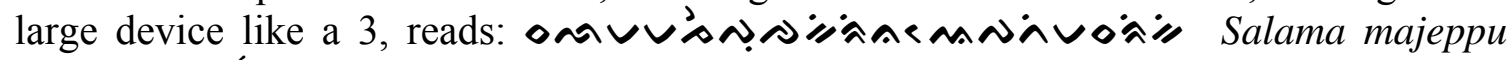
cangkiri'na É Patimasang Ringki-Peace indeed, bowl of I Patimasang Ringki. [The transcription of the personal name is very uncertain.] There is also an unexplained character within the text near the large device. Notice too the addition of the " below the line of the text. 


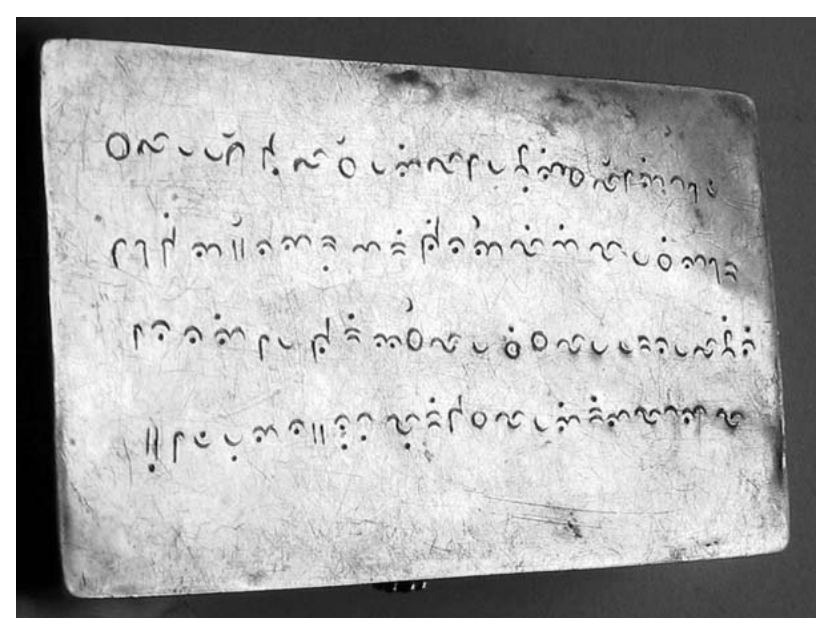

Figure 10: Inscription on the base of a small, silver sirih box with coffered lid containing a gilt panel. Dimensions of the box: length $9.8 \mathrm{~cm}$ long, width $5.6 \mathrm{~cm}$, height $3.0 \mathrm{~cm}$.

The text (Figure 10), with some expansion in transcription, reads:

Salama majeppu La Semmaila mébbui sale'é itoddang jompi angke'na aruwa ringgi' naelliwi La Masi oranéna I Ménggang riyaseng La Masi salama marana' mallabini kudé'mua nakanu' tulu ripasalama'i ri Alataala.

The translation poses some problems, especially in the last line, but the general intent is clear:

Peace indeed. La Ismael makes the writing underneath the box. Its worth is eight ringgits. La Masi buys it. The husband of Wé Ménggang, called La Masi, peace to his children and to the couple. If the cord [of friendship] be not burnt, may they be saved by God Almighty.

These short texts are highly stylised and repetitive so that it is possible to reflect more generally on their function. They all relate the object to one or more individuals, whatever the uncertainties of the proper transcription of those personal names. The sirih box also mentions a married couple by name and their children. In two cases - and there are others known as well - there is the declarative statement of weight or value. Writing is here serving to preserve or authenticate fact. This calls to mind Caldwell's hypothesis that the trigger for the origin of Bugis writing was the benefit of a relatively permanent and tangible record of specific genealogical information. 
A slightly different function can be seen in the short inscriptions found on the base, usually, of a class of spectacular reddish earthenware vessels from the early 20th century. Although one can trace elements of the manufacture and design of these objects back into other expressions of Bugis culture, this particular ware was produced essentially for sale to Europeans, perhaps especially Dutch officials and their wives (Macknight 1993b). Figures 11 and 12 show typical examples of the inscriptions. Again, personal names are important, though not as owners, since those for whom the items are intended lie, essentially, outside Bugis society, but as makers. These inscriptions are a statement of individuality, perhaps even of pride and a more modern sensibility. The use of Latin script for the place name in Figure 12 suggests a subtle hint of local identity. The Latin script might reflect the fact that representations of this would have been relatively common in signage or printed materials associated with the colonial state, whereas the potter might never have seen her own name in Latin script. Even familiarity, however, did not ensure accuracy as shown in Figure 11. I have discussed such inscriptions more fully elsewhere (Macknight 1993b: 165-167).

In a fine touch of irony, at roughly the same time, a series of plates were being produced in Europe decorated with painted Bugis, Makasar and even Arabic texts in lontara' script. Presumably, these were for sale in the Indies. Yayasan Harapan Kita (1998: 147) illustrates one example. A similar oddity, though produced in a Bugis context, is the sash presented to Matthes and decorated with several verses of poetry in both Bugis and Makasar; the forms of the lontara' characters - and some Arabic - are woven into the textile (van den Brink 1943: 588-590).

The use of lontara' in the publications of Pesantren As'adiyah has been noted above and the continuing practice of writing and reading Bugis in this script forms part of the educational experience in that institution. Outside that context, however, literacy in lontara', beyond the capacity to recognise a few characters, seems rare, especially among young people. The script lacks a function for people increasingly well educated about the modern world through the medium of Indonesian. ${ }^{15}$ 


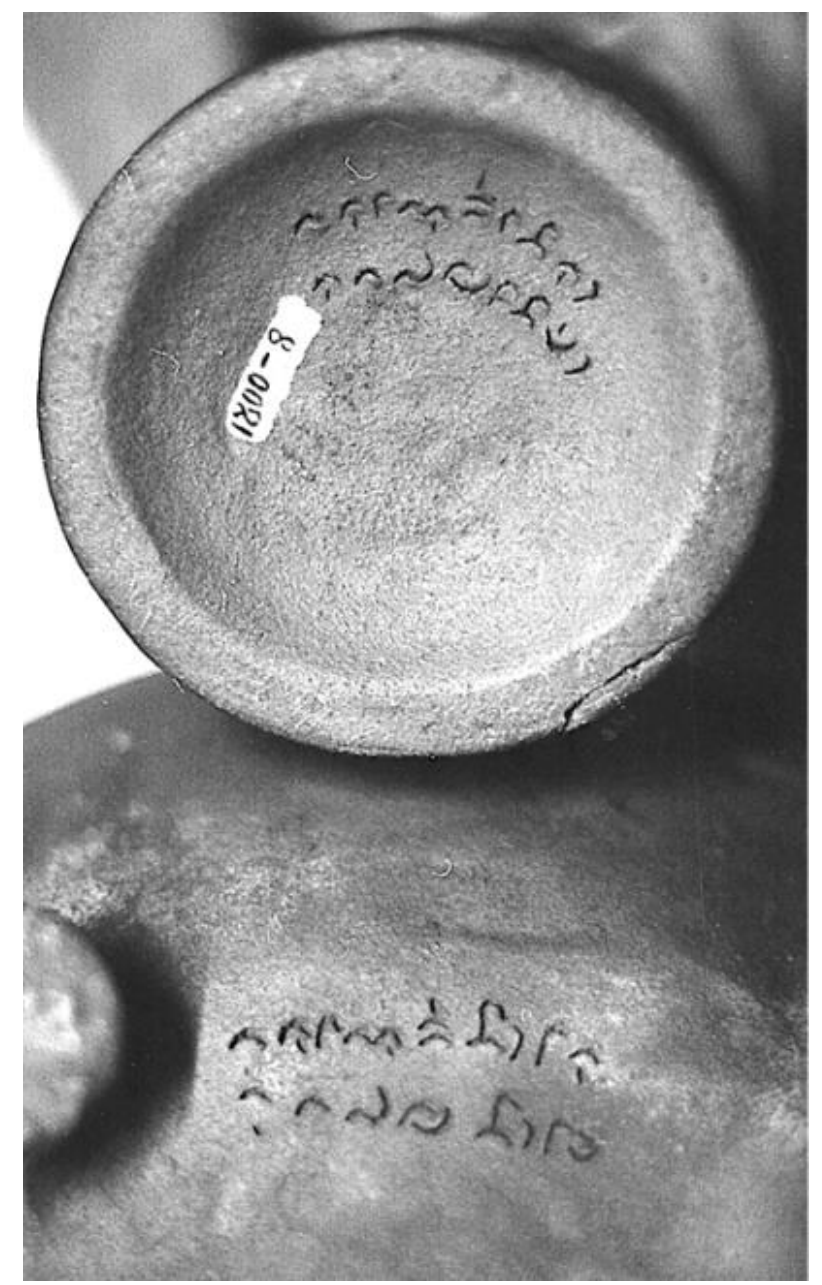

Figure 11: The bases of two pots, 1800-6 and 1800-8, in the Tropenmuseum, Amsterdam. Diameter of base of $1800-8$ is $10.1 \mathrm{~cm}$. The lower inscription reads: Tanaé riBoné/natappa Cabondéng - The land of Boné, Cabondéng formed. This potter signed many of her pots with an almost identical inscription. The upper inscription contains errors in the placement of the last two vowel markers on each line, producing the clearly erroneous forms: ... Béno and... Cabédong.

Occasionally, however, one finds lontara' in use. On 30 January 1999, I was wandering down the quay at Pasar Ikan harbour in Jakarta observing the many pinisi' which had brought cargoes of wood from Kalimantan and were loading up general cargo for the return voyage. Though all the vessels were now fitted with an engine, some capacity for sail had been retained on most and the twin rudders, hanging from the sterncastle, were still much in evidence. On the quayside, I noticed the name shown in Figure 13 and, a few hundred metres further on, the vessel itself, Jagawana Setia. Discussing the name on the quayside with two young crewman standing nearby, one from Bone and the other from Palopo in Sulawesi, I found that not only could they read the lontara', but they could also, without prompting, point 
out the minor errors. I was left to ponder the function of writing the name in lontara'; it is hard to imagine that anyone who could read the lontara' could not also read the Latin script. Nor could it be copied from the name on the vessel itself, since all vessels must have clearly displayed their name in Latin characters, and this name is Indonesian as well. I am left with the thought that it might represent a subtle assertion of Bugis identity in the national capital. Perhaps there is hope yet that the script will survive, whatever the medium of its use.

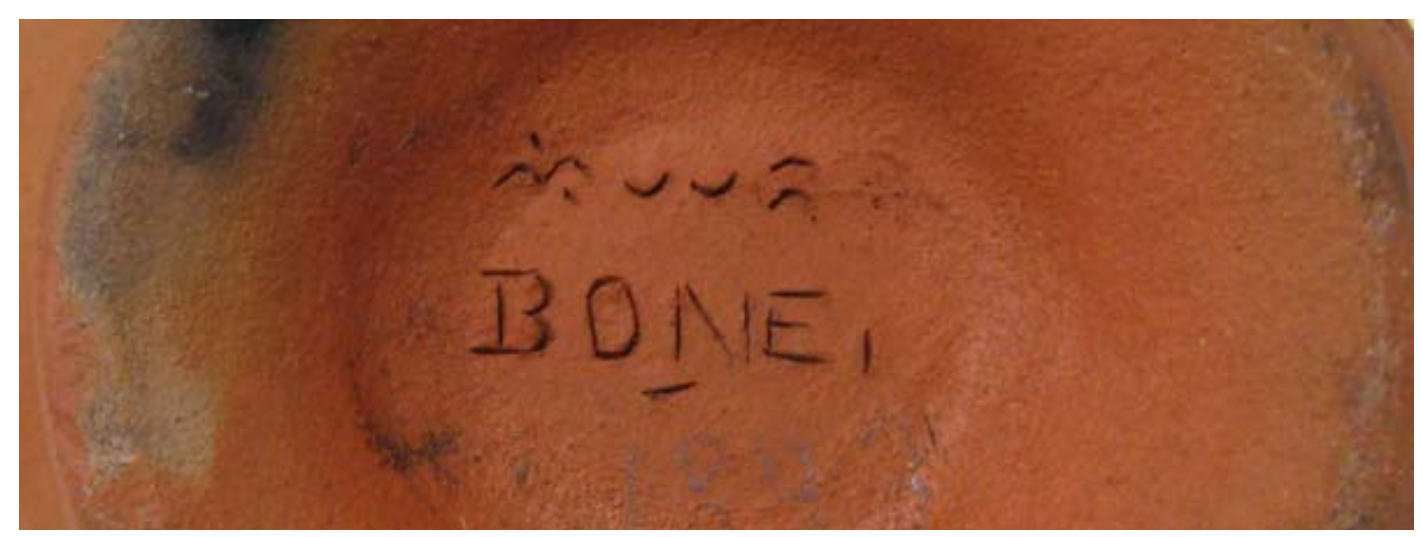

Figure 12: Base of a highly decorated earthenware pot. The top line of the inscription in lontara' is a personal name, I Mamara - though other transcriptions are possible. The bottom line, Bone, is a district in South Sulawesi. The pot was presented to the Swiss anthropologist, Alfred Bühler, in Kupang in 1935. The area of the pot shown in the photograph is c. $9 \mathrm{~cm}$ wide. Museum der Kulturen, Basel, IIc 6669a.

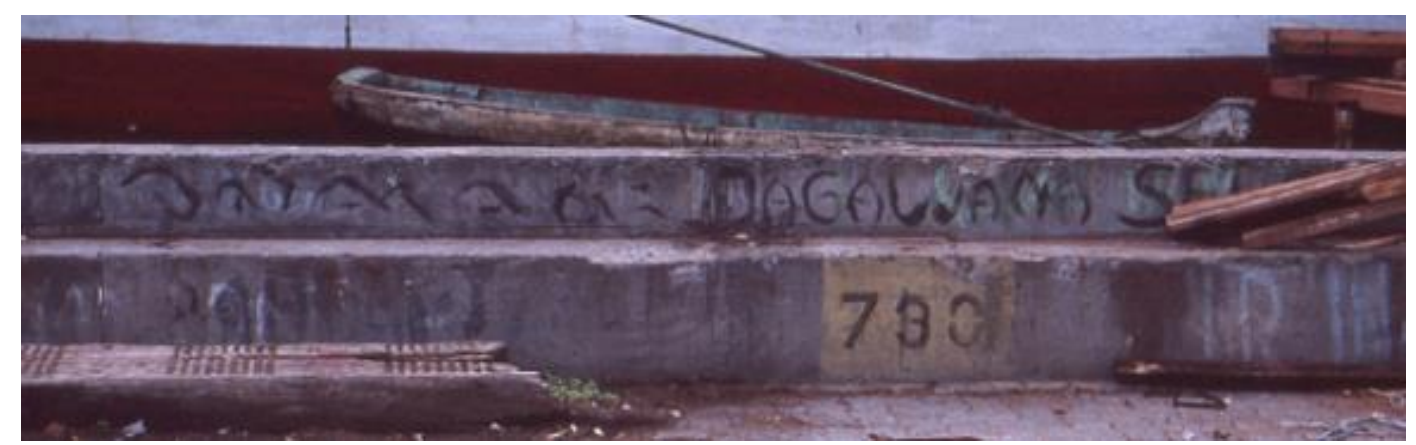

Figure 13: Prau name on the quayside, Pasar Ikan, Jakarta, 30 January 1999. The lontara' script reads $\Delta \wedge \wedge \wedge \Delta \wedge . .$. and the Latin script, Jagawana Setia. The Latin version is correct as proved by the presence of the vessel nearby. The name means "loyal keeper of the forest," which is somewhat ironic, given the cargoes of timber these praus were bringing from Kalimantan. There are several minor errors in the lontara': the third aksara should be $M$ with no dot (and the dot is in the less frequent position under the left arch), and before the fifth aksara there is no < marking the vowel for Sé. There should also be one final aksara for the last syllable of Setia. 


\section{ENDNOTES}

* Emeritus Professor Campbell Macknight is a Fellow in the Research School of Asian and Pacific Studies, The Australian National University, Canberra, Australia. He has longstanding interests in the Makassar-based trepang industry in northern Australia, pre- and proto-history in South Sulawesi and Bugis philology.

1 For variations in Bugis manuscript texts, see Macknight and Caldwell 2001. The uniqueness of a manuscript is - happily-compromised, to a significant extent, by microfilming and digital photography, even though some investigations, such as reading watermarks, require reference to the original.

2 Significant publications since Noorduyn's survey are another translation of the Bible (Kareba Madeceng 1997; see also Macknight 2009) and several volumes of La Galigo text (Salim et al. 1995; 2000; Fachruddin 1999 and Rahman 2006).

3 I am not aware of any printed example of Bugis in the serang script, derived from Arabic letters. For discussion of Bugis in serang script, see Cho (2012). This relative shortage of printed Bugis materials seems to explain an odd phenomenon that I have occasionally observed. Even well-educated Bugis speakers, with highly developed literacy in Indonesian and perhaps other languages as well, are remarkably casual in writing Bugis in Latin script; they frequently omit the glottal stop, fail to distinguish between [é] and [e], and are unsure about geminated consonants. In part, these problems can be explained by the inadequacies of the lontara' script and by different systems of Latin orthography, but these factors do not account for all the problems.

4 I thank my friend Wahyuddin Halim for showing me some of these As'adiyah publications and discussing his reseach on Pesantren As'adiyah with me.

5 In a broader context, the Bugis word for a written text, sure', seems to be a loan word from the Malay surat, though this goes back to an Austronesian root with the general idea of wound or cut (Adelaar 1995: 332).

6 Noorduyn (1993a: 567-568) suggests possible lines of derivation for / ka/ and /na/, but even these are not wholly convincing and they do not provide a consistent pattern for all aksara.

7 The closest parallel is perhaps the case of ogham, which seems to be an artificial series of signs devised on the template of an alphabet, probably the Latin alphabet though others are possible. The Korean hangul script, by contrast, relies on almost wholly new concepts.

8 The usual lack of a horizontal stroke in runes is attributed to the issue of legibility and the danger of splitting by cutting along the grain of a wooden surface.

9 This is item 131/59 in Juynboll 1925: 77. I have not handled the item myself.

10 The Tropenmuseum in Amsterdam contains another good example of a roll (668/215) though Kern, on the catalogue card, describes its contents as worthless. Kern (1939: 580-585) catalogues another roll in Leiden University Library. Tol (1996: 218) provides a good illustration of the roll he discusses elsewhere (Tol 2009). A recent example held in the National Archives office in Makassar is illustrated in several plates in Yayasan Harapan Kita (1998: 116, 117, 132).

11 I have argued elsewhere that the bulk of manuscripts in the La Galigo cycle implies access to paper (Macknight 1993a: 21). 
12 Some characters, apparently in jangan-jangan script, but not yet understood, are found inscribed on bricks from the Somba Opu fortress. They may be of slightly earlier date.

13 Similarly, the Bugis word for pen, kallang, is cognate with the Malay, kalam, and its antecedents to the west. In Bugis, kallang seems to refer specifically to a sharpened palm leaf rib and the distinction in the previous sentence between "pens made of ferns" and quills from ducks is worth noting.

14 I hope to publish a fuller description of these, and other inscribed silver items in my possession, in due course. All the inscriptions are of the same general type, though there are interesting variations in script. I again thank Wahyuddin Halim for much assistance with these texts.

15 For an excellent discussion of the contexts in which Bugis is spoken and those appropriate for Indonesian, see Mahmud (2008). This is the oral equivalent of the same issue.

\section{REFERENCES}

Adelaar, A. 1995. Asian roots of the Malagasy: A linguistic perspective. Bijdragen tot de Taal-, Land- en Volkenkunde 151 (3): 325-356.

Caldwell, I. A. 1988. South Sulawesi AD 1300-1600: Ten Bugis texts. PhD diss., Australian National University, Australia. . 1998. The chronology of the king list of Luwu' to AD 1611. In Living through histories: Culture, history and social life in South Sulawesi, eds. Robinson, K. and Paeni, M., 29-43. Canberra: Department of Anthropology, Research School of Pacific and Asian Studies, Australian National University/National Archives of Indonesia.

Cho, T. Y. 2012. Aksara sérang dan perkembangan tamadun Islam di Sulawesi Selatan. Yogyakarta: Penerbit Ombak.

Fachruddin Ambo Enre. 1999. Ritumpanna Wélenrénngé, Sebuah episoda sastra Bugis klasik Galigo. Jakarta: Ecole Française d'Extrême-Orient/Fakultas Sastra Universitas Indonesia/Yayasan Obor Indonesia.

Guillot, C. 1983. Le dluwang ou 'papier javanais'. Archipel 26 (1): 105-116.

Hamonic, G. and Salmon, C. 1983. La vie littéraire et artistique des Chinois peranakan de Makassar (1930-1950). Archipel 26 (1): 143-178.

Hirth, F. and Rockhill, W. W. 1911. Chau Ju-kua: His work on the Chinese and Arab trade in the twelfth and thirteenth centuries, entitled Chu-fan-chi. St Petersburg: Imperial Academy of Sciences.

Jacobs, H. T. T. M. 1971. A treatise on the Moluccas (c.1544). Probably the preliminary version of António Galvão's Lost História das Molucas (Sources and studies for the History of the Jesuits, volume 3). Rome/St. Louis: Jesuit Historical Institute. 
Jones, R. 1993. European and Asian papers in Malay manuscripts: A provisional assessment. Bijdragen tot de Taal-, Land- en Volkenkunde 149 (3): 474502.

Juynboll, H. H. 1925. Catalogus van 'sRijks Ethnographisch Museum, Deel 18. Celebes. II. Zuid-Celebes (Slot), Zuidoost- en Oost-Celebes en MiddenCelebes (1. Gedeelte). Leiden: Brill.

Kareba Madeceng: Kitta ri laleng basa Ugi esso-essoé. 1997. Jakarta: Lembaga Alkitab Indonesia.

Kern, R. A. 1939. Catalogus van de Boegineesche, tot den I La Galigo-cyclus behoorende handschriften der Leidsche Universiteitsbibliotheek alsmede van die in andere Europeesche bibliotheken. Leiden: Universiteitsbibliotheek.

Macknight, C. C. 1986. Changing perspectives in island Southeast Asia. In Southeast Asia in the 9th to 14th Centuries, eds. Marr, D. G. and Milner, A. C., 215-227. Singapore: Institute of Southeast Asian Studies/Canberra: Australian National University.

. 1993a. The early history of South Sulawesi: Some recent advances (working paper 81). Clayton: Centre of Southeast Asian Studies, Monash University.

. 1993b. Six pots from South Sulawesi. Records of the Australian Museum, Supplement 17: 159-171.

. 2009. Terjemahan dalam Bahasa Bugis. In Sadur: Sejarah terjemahan di Indonesia dan Malaysia, ed. Chambert-Loir, H., 265-272. Jakarta: Kepustakaan Populer Gramedia (KPG)/École française d'ExtrêmeOrient/Forum Jakarta-Paris/Pusat Bahasa/Universitas Padjadjaran.

Macknight, C. C. and Caldwell, I. A. 2001. Variation in Bugis manuscripts. Archipel 61 (1): 139-154.

Mahmud, M. 2008. Speaking Bugis and speaking Indonesian in South Sulawesi. Review of Indonesian and Malaysian Affairs 42 (2): 67-92.

Matthes, B. F. 1872. Boeginesche chrestomathie, 3 vols. Amsterdam: Spin.

Miller, C. 2013. Devanagari's descendants in North and South India, Indonesia and the Philippines. Writing Systems Research 2013: 1-15, http://dx.doi.org/10.1080/17586801.2013.857288. . Forthcoming. A Gujarati origin for scripts of Sumatra, Sulawesi and the Philippines. Proceedings of the Berkeley Linguistics Society 36: Writing Systems and Orthography.

Noorduyn, J. 1991. A critical survey of studies on the languages of Sulawesi. Leiden: KITLV Press.

. 1993a. Variation in the Bugis/Makasarese script. Bijdragen tot de Taal-, Land- en Volkenkunde 149 (3): 533-570.

. 1993b. A Bugis inscription in the Udok-Udok Cemetery, Brunei. Journal of the Malaysian Branch of the Royal Asiatic Society 66 (2): 103-112. 
Pelras, Ch. 1979. L'oral et l'écrit dans la tradition Bugis. Asie du Sud-est et Monde Insulindien (ASEMI) 10: 271-297. Reprinted, with minor alterations, in Pelras, Ch. 2010. Explorations dans l'univers des Bugis: Un choix de trente-trois rencontres. Paris: Cahier d'Archipel 39: 123-143. . 2016. Orality and writing among the Bugis, trans. Macknight, C. C. In Orality, writing and history: The literature of the Bugis and Makasar of South Sulawesi, ed. Druce, S. C. International Journal of Asia Pacific Studies 12 (Supp. 1): 13-51, http://dx.doi.org/10.21315/ijaps2016.12.s1.3.

Rahman, N. 2006. Cinta, laut, dan kekuasan dalam epos La Galigo. Makassar: La Galigo Press.

Salim, M. et al. 1995. I La Galigo menurut naskah NBG 188 yang disusun oleh Arung Pancana Toa, vol. 1. Jakarta: Djambatan dan KITLV. . 2000. La Galigo menurut naskah NBG 188 yang disusun oleh Arung Pancana Toa, vol. 2. Makassar: Lembaga Penerbitan Universitas Hasanuddin.

Tol, R. 1996. A separate empire: Writing of South Sulawesi. In Illuminations: The writing traditions of Indonesia, eds. Kumar, A. and McGlynn, J. H., 213230. New York and Tokyo: Weatherill. . 2009. Rolled up Bugis stories: Marriage advice and the tale of the parakeet. Review of Indonesian and Malaysian Affairs 43 (1): 189-208.

van den Brink, H. 1943. Dr. Benjamin Frederik Matthes: Zijn leven en arbeid in dienst van het Nederlandsch Bijbelgenootschap. Amsterdam: Nederlandsch Bijbelgenootschap.

Yayasan Harapan Kita. 1998. Indonesia indah 9 aksara. Jakarta: Yayasan Harapan Kita/BP3TMII. 